\title{
CHANNELS OF PRODUCT FORMATION AND EXCITED MOLECULES RELAXATION AT MULTIPHOTON DISSOCIATION OF CHLORODIFLUOROMETHANE
}

\author{
V. A. DIMAND, K. K. MALTZEV, A. A. NADEIKIN, A. I. NIKITIN, \\ A. M. VELICHKO and A. V. VNUKOV \\ Institute of Energy Problems of Chemical Physics, Russian Academy of Sciences, \\ Leninsky prospect, 38, B-334, Moscow, 117829, Russia
}

(Received 19 February 1992)

$\mathrm{C}_{2} \mathrm{~F}_{4}$ molecules have been for the first time directly proved to be generated in the reaction of vibrationally-excited molecules $\mathrm{CF}_{2} \mathrm{HCl}$. The contribution of this reaction to $\mathrm{CF}_{2} \mathrm{HCl}$ multiphoton dissociation (MPD) products formation was shown to become predominant at the initial $\mathrm{CF}_{2} \mathrm{HCl}$ pressures about ten Torr. Also fast relaxation of the highly excited molecules $\mathrm{CF}_{2} \mathrm{HCl}$ on the product molecules $\mathrm{C}_{2} \mathrm{~F}_{4}$ was discovered.

KEY WORDS : Multiphoton dissociation, chlorodifluoromethane, vibrational relaxation, vibrationallyexcited molecules.

\section{INTRODUCTION}

Chlorodifluoromethan $\left(\mathrm{CF}_{2} \mathrm{HCl}\right)$ is known to be one of the most convenient gases for carbon isotope's laser separation. ${ }^{1-4}$ Under $\mathrm{CO}_{2}$-laser irradiation $\mathrm{CF}_{2} \mathrm{HCl}$ molecules can absorb several quanta and then dissociate:

$$
\mathrm{CF}_{2} \mathrm{HCl}+\mathrm{nh} v \rightarrow \mathrm{CF}_{2} \mathrm{HCl}^{*} \rightarrow \mathrm{CF}_{2}+\mathrm{HCl} .
$$

$\mathrm{CF}_{2}$-radicals recombination leads to the product formation:

$$
\mathrm{CF}_{2}+\mathrm{CF}_{2}+\mathrm{M} \rightarrow \mathrm{C}_{2} \mathrm{~F}_{4}+\mathrm{M} \text {. }
$$

It was found that $\mathrm{CF}_{2} \mathrm{HCl}$ decomposition rate and selectivity remain quite high up to pressures of several tens of torr. ${ }^{5-8}$ On the basis of mass-spectrometer analysis of carbon isotope's distribution data in $\mathrm{C}_{2} \mathrm{~F}_{4}$ authors of Ref. 9 supposed that in addition to (2) one more reaction takes part in $\mathrm{C}_{2} \mathrm{~F}_{4}$-production. Most probably this reaction is a direct interaction between two vibrationally excited molecules of $\mathrm{CF}_{2} \mathrm{HCl}^{*}$ :

$$
\mathrm{CF}_{2} \mathrm{HCl}^{*}+\mathrm{CF}_{2} \mathrm{HCl}^{*} \rightarrow \mathrm{C}_{2} \mathrm{~F}_{4}+2 \mathrm{HCl} \text {. }
$$

It was shown that selectivity of reaction (3) is high enough and its contribution into the product formation increases with $\mathrm{CF}_{2} \mathrm{HCl}$ pressure. ${ }^{9}$ Nevertheless, all evidences 
for involvement of reaction (3) were indirect and it was interesting to find direct confirmation of reaction (3) existence. Since the presence of $\mathrm{CF}_{2}$ radicals in the (1)st channel and their absence in the (3) rd one is an important difference between channels (1) and (3), it is quite reasonable to measure $\mathrm{CF}_{2}$-radicals concentration after $\mathrm{CO}_{2}$-laser pulse and $\mathrm{C}_{2} \mathrm{~F}_{4}$ concentration when all reactions have been completed. If the results would show that the amount of $\mathrm{C}_{2} \mathrm{~F}_{4}$ is greater than half of $\mathrm{CF}_{2}$-radicals amount, then one can consider that the reaction (3) is responsible for this exceeding.

This paper is devoted to description of the results of such experiments. We managed to prove the reaction ( 3 ) existence and evaluate its contribution to the final products formation at different $\mathrm{CF}_{2} \mathrm{HCl}$ pressures and also to study the influence of the reaction products $-\mathrm{C}_{2} \mathrm{~F}_{4}$ and $\mathrm{HCl}-$ accumulation on the value of multiphoton dissociation yield of $\mathrm{CF}_{2} \mathrm{HCl}$ molecules.

\section{EXPERIMENT}

$\mathrm{CF}_{2}$-radicals absorb ultraviolet radiation in the $235-258 \mathrm{~nm}$ band $\left(\tilde{\mathrm{A}}\left({ }^{1} \mathrm{~B}_{1}\right) \leftarrow\right.$ $\tilde{\mathrm{X}}\left({ }^{1} \mathrm{~A}_{1}\right)$ electron transition $) .{ }^{10}$ Vibrational levels $\mathrm{v}_{1}^{\prime}=0, \mathrm{v}_{2}^{\prime}=2$ of the upper electron state and $v_{1}^{\prime \prime}=0, v_{2}^{\prime \prime}=0$ of the lower one take part in the absorption near $248.8 \mathrm{~nm}$. Extinction coefficient in the maximum of absorption band $(\lambda=249 \mathrm{~nm})$ at the temperature $298 \mathrm{~K}$ (to the base 10 ) is $\varepsilon_{10}^{249}=7620 \pm 4001 /(\mathrm{mole} \cdot \mathrm{cm}$ ). (The absorption cross-section is $\left.\sigma=2.91 \cdot 10^{-17} \mathrm{~cm}^{2}\right) .{ }^{11}$ Absorption coefficient decreases with temperature growth: on $\lambda=248.2 \mathrm{~nm}$ extinction coefficient $\varepsilon_{10}^{248}$ at $\mathrm{T}=1804 \mathrm{~K}$ is $1300 \mathrm{l} /(\mathrm{mole} \cdot \mathrm{cm})\left(\sigma=4.96 \cdot 10^{-18} \mathrm{~cm}^{2}\right)$, at $\mathrm{T}=2085 \mathrm{~K} \varepsilon_{10}^{248}=10651 /(\mathrm{mole} \cdot \mathrm{cm})$ and at $\mathrm{T}=2875 \mathrm{~K} \quad \varepsilon_{10}^{248}=813 \mathrm{l} /(\mathrm{mole} \cdot \mathrm{cm}) .{ }^{12}$ For vibrational temperature $\mathrm{T}_{\mathrm{v}}=725 \mathrm{~K} \quad \varepsilon_{10}^{249}=3875 \pm 3001 /($ mole $\cdot \mathrm{cm})\left(\sigma=1.48 \cdot 10^{-17} \mathrm{~cm}^{2}\right){ }^{13}$ These data allow one to find approximate values of absorption cross-section for another temperatures.

In our experiments $\mathrm{KrF}$-excimer laser radiation was used to probe the gas and determine $\mathrm{CF}_{2}$-radicals concentration $\left(\lambda_{\mathrm{KrF}}=248 \mathrm{~nm}\right)$. Absorption cross-section value for $\mathrm{CF}_{2} \mathrm{HCl}$ at this wavelength does not exceed $\sigma=10^{-26} \mathrm{~cm}^{2}$ (Ref. 14) - that is much more lower than this one for $\mathrm{CF}_{2}$. As laser pulse duration is $15-20 \mathrm{~ns}$, only radicals on the definite vibrational-rotational level can interact with $\mathrm{KrF}$-laser irradiation. Really, the time between two collisions of $\mathrm{CF}_{2} \mathrm{HCl}$ molecule can be evaluated to be not less than $80 \mathrm{~ns}$ at $\mathrm{CF}_{2} \mathrm{HCl}$ pressure of 1 Torr. Since 5-10 collisions must occur the rotational relaxation to be completed one can consider that under the probing laser pulse duration $\tau_{1}=20 \mathrm{~ns}$ the molecule remains 'free' for the process of UV quanta absorption up to pressures of 20-40 Torr. That is why raise of radicals population on this level owing to vibrational-rotational exchange with the neighbouring levels can be neglected. This leads to a little less absorption of UV radiation than in the case when equilibrium population of lower level is maintained (at probing of the gas with continuous wave light, for example), but, on the other hand, this makes our method insensitive to gas pressure changes.

The apparatus scheme for the measurements of $\mathrm{CF}_{2}$-radicals concentration is presented in Figure 1. TEA $\mathrm{CO}_{2}$-laser beam 13, transmitted through the telescope 


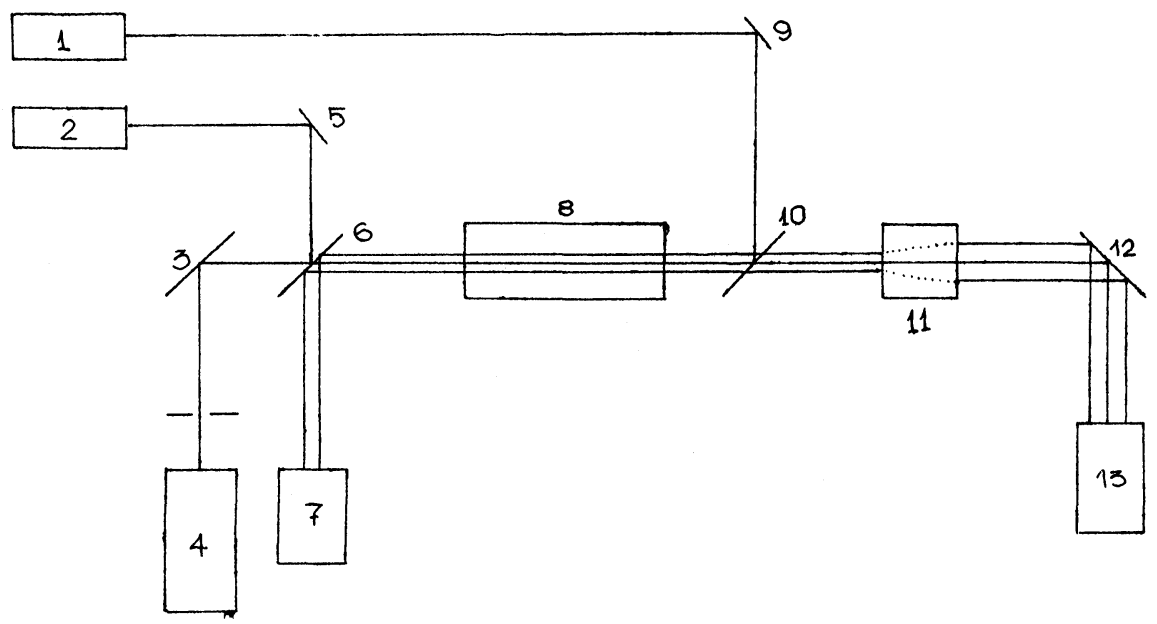

Figure 1 The apparatus for the measurements of $\mathrm{CF}_{2}$-radicals concentration.

11, passes along the axis of the cell 8 . The stainless steel cell is used, its internal diameter is $3 \mathrm{~cm}$ and length is $10 \mathrm{~cm}$; windows are made from $\mathrm{BaF}_{2}$. Diameter of $\mathrm{CO}_{2}$-laser beam at the entrance and at the exit of the cell is $1.2 \mathrm{~cm}$. Part of the laser beam, passing through the cell, is declined by the beam splitter 6 to the entrance of calorimeter 7-it permits to measure irradiation energy which passes through the cell. To measure the $\mathrm{CO}_{2}$-laser energy at the entrance of the cell we use one more calorimeter to receive the beam declined by the beam splitter 10 .

Probing UV-laser 4 beam is directed by mirror 3 along the cell axis towards $\mathrm{CO}_{2}$-laser beam. Diameter of UV-laser beam at the entrance and at the exit of the cell is $\sim 0.3 \mathrm{~cm}$. Part of the beam is directed to the photodetector 2 by plate 6 and mirror 5. After passing the cell part of the beam is reflected by plate 10 and mirror 9 to photodetector 1. The photodiodes PD21-KP were used as the detectors of UV-irradiation. These photodiodes are weakly sensitive to $248 \mathrm{~nm}$ wavelength irradiation, therefore the cells with rhodamine $6 \mathrm{G}$ solution in isopropanol were placed in the front of each of them. Thickness of these cells was $2 \mathrm{~mm}$ and diameter was $8 \mathrm{~mm}$. Solution of the rhodamine was hermetically sealed by polypropylene films of $40 \mu \mathrm{m}$ thickness. To avoid electromagnetic hindrances from electrical discharge of the lasers, we refused from wide band amplifier of the photodiode signal and used two-staged amplifier with amplification factor $\sim 10^{3}$ with internal time constant $\tau_{\mathrm{PD}} \approx 2 \cdot 10^{-5} \mathrm{~s}$. The shape of the signal at the exit of such amplifier is defined by time parameters of the amplifying path, and the amplitude of the signal with accuracy of $\tau_{1} / \tau_{\mathrm{PD}}=10^{-3}$ ( $\tau_{1}$ is duration of UV-laser pulse) is proportional to the integral of the probing beam intensity. ${ }^{15}$ This proportionality remains constant while the voltage of electric signal from photodiode is much less than characteristic voltage of its internal electric field; just for the photodiode that operates in photovoltage regime this voltage of $\mathrm{p}-\mathrm{n}$ transition is about $0.6 \mathrm{~V}$. In our case the maximum photodiode signal amplitude was $1 \mathrm{mV}$, therefore one can consider that our measurements were 
performed in the linear regime. With the aid of pulse generator G5-60 and specially made synchronization of excimer and $\mathrm{CO}_{2}$-lasers scheme delay between $\mathrm{UV}$ and IR-pulses could be varied from 0 to $30 \mu \mathrm{s}$.

The measurements of the amplitudes of amplified signals were carried out with the help of oscilloscope C9-8, which was interfaced by the adapter for general use to IBM PC AT. The program was made so that after each pulse the measured data from both photoreceptors were delivered to PC AT, where they were treated and stored. The relative absorption of the probing beam was determined by the expression :

$$
\mathrm{I} / \mathrm{I}_{0}=\mathrm{k} \cdot\left(\mathrm{U}_{1} / \mathrm{U}_{2}\right),
$$

where $I, I_{0}$ are the intensities of the probing and calibrating beams, respectively, $U_{1}$, $\mathrm{U}_{2}$ are the amplitudes of the signals from the photoreceptors 1 and $2, \mathrm{k}$ is the setting factor which was determined from the condition that $I / I_{0}=1$ when there are no particles in the cell which can absorb $\mathrm{KrF}$-laser irradiation.

To check laser spectrometer operation we filled optical gas cell with $\mathrm{SO}_{2}$. It was found that up to 30 torr transmitted light intensity attenuation followed the Lambert-Beer law, and absorption cross-section of $\mathrm{SO}_{2}$ at $\lambda=248 \mathrm{~nm}$ turned out to be $(7.5 \pm 0.3) \cdot 10^{-20} \mathrm{~cm}^{2}$, that is near to data of Ref. 14. Under $\mathrm{CO}_{2}$-laser influence ( simultaneously at lines $9 \mathrm{R}(32)-9 \mathrm{R}(38)$ ) on $\mathrm{CF}_{2} \mathrm{HCl}$ absorption at $\lambda=248 \mathrm{~nm}$ was found. We attributed it to $\mathrm{CF}_{2}$ radicals appearance in the irradiated gas volume. Weakening of UV signal increased with the increase of a delay between $\mathrm{CO}_{2}$ and $\mathrm{KrF}$-lasers pulses from 0 up to $10 \mu$ s, then (up to $30 \mu \mathrm{s}$ ) it remained constant. Radicals $\mathrm{CF}_{2}$ concentration growth after $\mathrm{CO}_{2}$-laser pulse finishing is due to after-pulse decomposition of $\mathrm{CF}_{2} \mathrm{HCl}$ vibrationally-overexcited molecules. Within this time range one can disregard the influence of recombination (2) on $\mathrm{CF}_{2}$ decreasing (characteristic time of this reaction at the initial $\mathrm{CF}_{2}$ concentration of $10^{15} \mathrm{~cm}^{-3}$ is about $30 \mathrm{~ms}$ ). ${ }^{16}$

The calibration of laser spectrometer, was done by the following way. The cell was filled with the mixture $\mathrm{CF}_{2} \mathrm{HCl}: \mathrm{Ar}=20: 1$ at the pressure of 2.1 Torr to be irradiated by 11 pulses of $\mathrm{CO}_{2}$-laser with energy density of $1.26 \mathrm{~J} / \mathrm{cm}^{2}$. The attenuation of the probing UV pulse, delayed a time $9.6 \mu \mathrm{s}$ with respect to the beginning of $\mathrm{CO}_{2}$-laser pulse, for the first pulse of a series makes up $I / I_{0}=0.97 \pm 0.02$. With the help of mass-spectrometer analysis of the content of the irradiated gas the yield of $\mathrm{CF}_{2} \mathrm{HCl}$-dissociation per pulse was found. The dissociation yield was determined with the expression: ${ }^{17}$

$$
\mathrm{N}_{\mathrm{n}} / \mathrm{N}_{0}=(1-\alpha \cdot \beta)^{n} \text {, }
$$

where $\mathrm{N}_{\mathrm{n}} / \mathrm{N}_{0}=\left(\mathrm{H}_{51} / \mathrm{H}_{40}\right)_{11} /\left(\mathrm{H}_{51} / \mathrm{H}_{40}\right)_{0},\left(\mathrm{H}_{51}\right)_{0}$ and $\left(\mathrm{H}_{51}\right)_{11}$ are respectively heights of the ion peaks $\mathrm{m} / \mathrm{e}=51$ of $\mathrm{CF}_{2} \mathrm{HCl}$-molecule mass-spectrum before and after gas irradiation by 11 pulses of $\mathrm{CO}_{2}$-laser, $\left(\mathrm{H}_{40}\right)_{0}$ and $\left(\mathrm{H}_{40}\right)_{11}$ are heights of the ion peaks $\mathrm{m} / \mathrm{e}=40$ of argon (argon was used in our experiments as a bench-mark) before and after irradiation of the mixture, $n$ is a number of pulses $(n=11), \alpha$ is the fraction of the cell volume illuminated by the $\mathrm{CO}_{2}$-laser $(\alpha=0.18)$. While substituting to the expression (5) the measured value $\mathrm{N}_{\mathrm{n}} / \mathrm{N}_{0}=0.97 \pm 0.02$, one can find $\beta=0.014 \pm 0.0003$, but it also means that $\mathrm{CF}_{2}$-radicals concentration in the irradiated volume is equal $\mathrm{n}_{\mathrm{CF}_{2}}=\beta \cdot \mathrm{n}_{\mathrm{CF}_{2} \mathrm{HCl}}=10^{15} \mathrm{~cm}^{-3}$. The cross section for 
absorption of UV laser radiation by $\mathrm{CF}_{2}$-radicals is $\sigma=\left(\ln \left(\mathrm{I}_{0} / \mathrm{I}\right)\right) /\left(\mathrm{n}_{\mathrm{CF}_{2}} \cdot \mathrm{L}\right)=$ $3 \cdot 10^{-18} \mathrm{~cm}^{2}$ (here $\mathrm{I}_{0} / \mathrm{I}$ is the deviation of UV laser intensities at the entrance and at the exit of the optical cell, which length is $10 \mathrm{~cm}$ ). The obtained value of $\sigma$ is approximately 3 times lower than the value found in Ref. 18 at the MPD of $\mathrm{CF}_{2} \mathrm{HCl}$ investigation where the vibrational temperature of radicals was considered to be $1160 \mathrm{~K}$. This discrepancy of the results more obviously is caused by the difference in experimental conditions: in Ref. 18 the data were obtained with probing the cell with the continuous wave light, when the molecules of a few vibrational-rotational levels, which are disposed not far from each other, can interact with the beam, while in our case, when the probing is produced by a short pulse of light, only the molecules of the single vibrational-rotational level may take part in absorption.

\section{RESULTS AND DISCUSSION}

In Figure 2 the experimental results on concentration of $\mathrm{C}_{2} \mathrm{~F}_{4}$ produced in the irradiated volume (squares) and concentration of $\mathrm{CF}_{2}$-radicals in the same volume (crosses) dependences on $\mathrm{CF}_{2} \mathrm{HCl}$-pressure are shown. For more convenient comparing of the results the scale of ordinate for $\mathrm{C}_{2} \mathrm{~F}_{4}$ molecules is made two times greater than the scale for $\mathrm{CF}_{2} \cdot \mathrm{CF}_{2}$-radicals concentration was measured according to the technique described in the previous part. $\mathrm{C}_{2} \mathrm{~F}_{4}$ concentration after $\mathrm{n}$ laser pulses was determined with the help of mass-spectrometer analysis by the diminishing of $\mathrm{CF}_{2} \mathrm{HCl}$ concentration:

$$
\left[\mathrm{C}_{2} \mathrm{~F}_{4}\right]_{(\mathrm{n})}=\frac{1}{2} \cdot\left(\mathrm{N}_{0}-\mathrm{N}_{\mathrm{n}}\right) .
$$

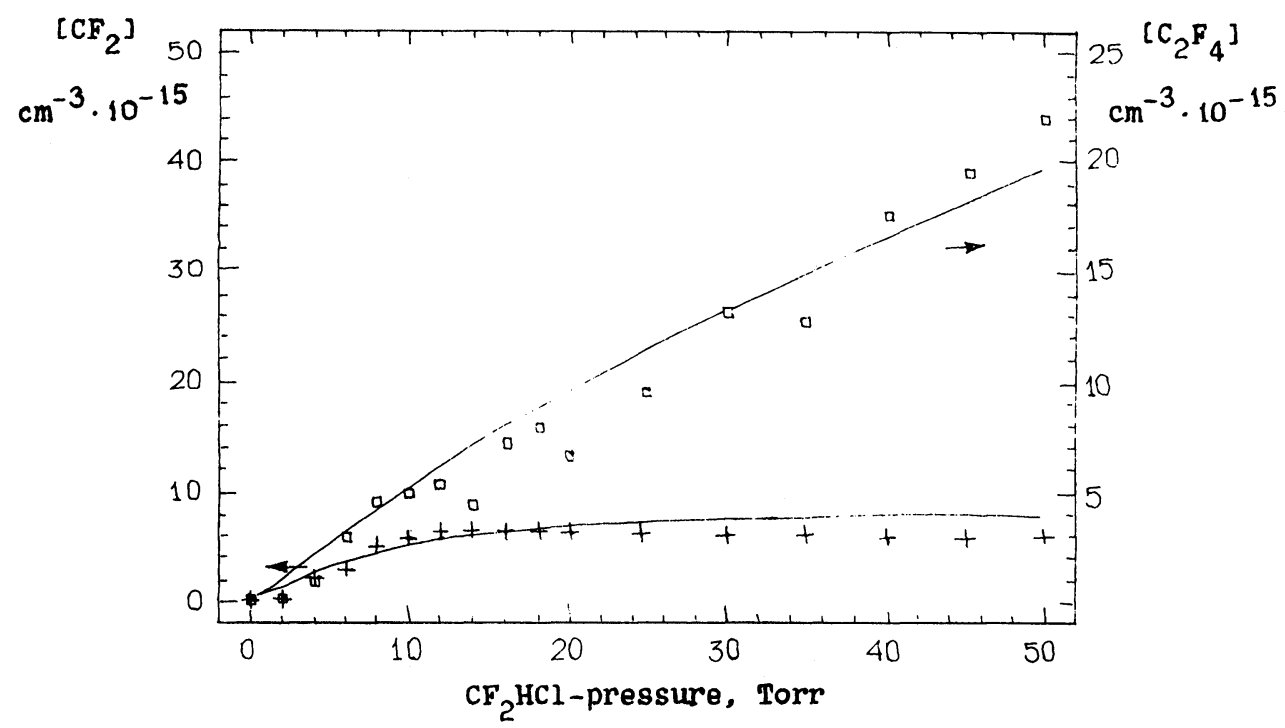

Figure 2 Experimental and calculated dependencies of $\mathrm{C}_{2} \mathrm{~F}_{4}$ concentration $(\square)$ and $\mathrm{CF}_{2}$ concentration $(+)$ on the initial pressure of $\mathrm{CF}_{2} \mathrm{HCl}$. 
where $\left[\mathrm{C}_{2} \mathrm{~F}_{4}\right]_{(\mathrm{n})}-\mathrm{C}_{2} \mathrm{~F}_{4}$ concentration in the reaction cell after the n-th $\mathrm{CO}_{2}$-laser pulse, $\mathrm{N}_{0}-\mathrm{CF}_{2} \mathrm{HCl}$ concentration before irradiation, $\mathrm{N}_{\mathrm{n}}-\mathrm{CF}_{2} \mathrm{HCl}$ concentration after the $n$-th pulse. Using expression (5) one can easily determine $\mathrm{C}_{2} \mathrm{~F}_{4}$ concentration in the reaction cell after the first $\mathrm{CO}_{2}$-laser pulse:

$$
\left[\mathrm{C}_{2} \mathrm{~F}_{4}\right]_{(1)}=\frac{1}{2} \cdot \mathrm{N}_{0} \cdot\left(1-\left(\mathrm{N}_{\mathrm{n}} / \mathrm{N}_{0}\right)^{1 / \mathrm{n}}\right) \text {. }
$$

It can be seen from Figure 2 that in the range of $\mathrm{CF}_{2} \mathrm{HCl}$ pressures from 0 to 4 Torr $\mathrm{C}_{2} \mathrm{~F}_{4}$ concentration is two times lower than $\mathrm{CF}_{2}$ concentration in the limits of the experimental error. Since two radicals $\mathrm{CF}_{2}$ can form only one molecule $\mathrm{C}_{2} \mathrm{~F}_{4}$ and there is no other ways of $\mathrm{CF}_{2}$ radicals elimination from the system, this result means that in this range of $\mathrm{CF}_{2} \mathrm{HCl}$-pressures $\mathrm{CF}_{2}$-radicals recombination is the single source of $\mathrm{C}_{2} \mathrm{~F}_{4}$ formation. When pressure is higher than 4 Torr the quantity of $\mathrm{C}_{2} \mathrm{~F}_{4}$ formed becomes more greater than the quantity which may be formed in the process of $\mathrm{CF}_{2}$ recombination. It means that when increasing $\mathrm{CF}_{2} \mathrm{HCl}$ pressure one more channel of $\mathrm{C}_{2} \mathrm{~F}_{4}$ formation appears and this channel is more probably the reaction (3). The contribution of this second channel increases with $\mathrm{CF}_{2} \mathrm{HCl}$ pressure increase; so at 20 Torr the contribution of the second reaction over-exceeds the contribution of the first one approximately in 1.5 times.

In the range of $\mathrm{CF}_{2} \mathrm{HCl}$ pressures lower than 8 Torr the increase of $\mathrm{CF}_{2}$ radicals concentration was observed, although at the following increasing of gas pressure in the cell radical concentration practically did not change. If one can suggest, that the value of dissociation yield does not depend upon initial gas pressure, the linear growth of radical concentration vs gas pressure should take place. The observed deviation from linear dependence can be explained if non-uniformity of $\mathrm{CO}_{2}$-laser power density along the cell is taken into account, higher is the gas pressure, more strongly does this non-uniformity reveal itself.

Let us consider that $\mathrm{CO}_{2}$-laser power density $\Phi$ changes along the cell according to the expression:

$$
\Phi=\Phi_{0} \cdot \exp \left(-\sigma_{\mathrm{CO}_{2}} \cdot \mathrm{N}_{\mathrm{M}} \cdot 1\right),
$$

where $\Phi_{0}$ is $\mathrm{CO}_{2}$-laser power density at the entrance of the cell, $\sigma_{\mathrm{CO}_{2}}$ is cross-section for absorption of $\mathrm{CO}_{2}$-laser beam by chlorodifluoromethane molecules, $\mathrm{N}_{\mathrm{M}}$ is $\mathrm{CF}_{2} \mathrm{HCl}$ concentration, 1 is distance from the entrance to the cell. It was found that within the experimental error this law is fulfilled quite perfectly. For dependence of dissociation yield on $\mathrm{CO}_{2}$-laser power density one can use the expression $\beta \sim \Phi^{\mathrm{m}},{ }^{17}$ where $m$ is a constant. So one can consider that dissociation yield would change along the cell according to the expression:

$$
\beta(1)=\beta_{0} \cdot \exp \left(-\mathrm{m} \cdot \sigma_{\mathrm{CO}_{2}} \cdot \mathrm{N}_{\mathrm{M}} \cdot 1\right),
$$

where $\beta_{0}$ is dissociation yield value at the entrance of the cell at power density $\Phi_{0}$. Since $\mathrm{CF}_{2}$-radicals concentration is proportional to dissociation yield $\beta$, its change is described by the expression analogous to (9):

$$
\mathrm{n}(1)=\mathrm{n}_{0} \cdot \exp \left(-\mathrm{m} \cdot \sigma_{\mathrm{CO}_{2}} \cdot \mathrm{N}_{\mathrm{M}} \cdot 1\right),
$$

where $\mathrm{n}(1)$ is $\mathrm{CF}_{2}$ radicals concentration at the distance 1 from the entrance of the 
cell, and $\mathrm{n}_{0}=\mathrm{n}(0)$. While treating the experimental results this dependence was not taken into account, and $\mathrm{CF}_{2}$ radicals concentration was considered to be constant along all the cell. So we determined the $\mathrm{CF}_{2}$ concentration averaged along the axis of the cell $\mathrm{n}_{\text {eff }}$, which is connected with $\mathrm{n}_{0}$ by the following expression:

$$
\mathrm{n}_{\text {eff }}=\mathrm{n}_{0} \cdot \frac{\left(1-\left(\Phi_{\mathrm{L}} / \Phi_{0}\right)^{\mathrm{m}}\right)}{\mathrm{m} \cdot \ln \left(\Phi_{0} / \Phi_{\mathrm{L}}\right)}
$$

where $\Phi_{\mathrm{L}}$ is $\mathrm{CO}_{2}$-laser power density at the exit of the cell, or in a different way :

$$
\mathrm{n}_{\text {eff }}=\mathrm{n}_{0} \cdot \frac{\left(1-\exp \left(-\mathrm{m} \cdot \sigma_{\mathrm{CO}_{2}} \cdot \mathrm{N}_{\mathrm{M}} \cdot \mathrm{L}\right)\right)}{\mathrm{m} \cdot \sigma_{\mathrm{CO}_{2}} \cdot \mathrm{N}_{\mathrm{M}} \cdot \mathrm{L}} .
$$

Using the above mentioned suggestion about the independence of dissociation yield on gas pressure, i.e. $\mathrm{n}_{0}=\beta_{0} \cdot \mathrm{N}_{\mathrm{M}}$, one can see that while enhancing pressure

$$
\lim _{\mathrm{N}_{\mathrm{M}} \rightarrow \infty} \mathrm{n}_{\text {eff }}=\frac{\beta_{0}}{\mathrm{~m} \cdot \sigma_{\mathrm{CO}_{2}} \cdot \mathrm{L}},
$$

the value of the measured $\mathrm{CF}_{2}$ concentration should approach a constant, and that was experimentally observed. The experimental dependence may be approximated by the function $\mathrm{y} \equiv \mathrm{A} \cdot(1-\exp (-\mathrm{B} \cdot \mathrm{X}))$ and one can find with the help of the least square method the values of the coefficients $A$ and $B$. Using the expressions (12) and (13) it is easy to get the values $\mathrm{m}=1.03$ and $\beta_{0}=0.024$. The curve with these parameters is shown in Figure 2. The main feature of the dependence of the relation of $\mathrm{C}_{2} \mathrm{~F}_{4}$ concentration to $\mathrm{CF}_{2}$ concentration upon $\mathrm{CF}_{2} \mathrm{HCl}$ pressure is the growth of this relation in all investigated range of pressures. The growth of this relation at low pressures may be explained, if one takes into account that the reaction of the excited molecules is the bimolecular reaction. Product yield of this reaction is proportional to the second power of excited molecules concentration:

$$
\mathrm{P}_{\mathrm{r}}(1) \sim \mathrm{n}^{*}(1)^{2}=\mathrm{n}^{* 2} \cdot \exp \left(-2 \cdot \mathrm{m} \cdot \sigma_{\mathrm{CO}_{2}} \cdot \mathrm{N}_{\mathrm{M}} \cdot 1\right),
$$

and if one would make a supposition about proportionality of excited molecules concentration to the initial concentration of chlorodifluoromethane $\mathrm{N}_{\mathrm{M}}$, the expression for $\operatorname{Pr}(1)$ would be :

$$
\left.\mathbf{P}_{\mathrm{r}}(1)=\gamma \cdot \mathbf{N}_{\mathrm{M}}^{2} \cdot \exp \left(-2 \cdot \mathrm{m} \cdot \sigma_{\mathrm{CO}_{2}} \cdot \mathbf{N}_{\mathrm{M}} \cdot 1\right)\right),
$$

where $\gamma$ is a coefficient.

Full change of chlorodifluoromethane concentration (as the result of dissociation and reaction) measured with mass-spectrometer should be described by the expression:

$$
\begin{aligned}
\left|\Delta \mathrm{N}_{\mathrm{M}}\right|_{\mathrm{ms}}= & \chi \cdot \mathrm{N}_{\mathrm{M}} \cdot\left(1-\exp \left(-2 \cdot \mathrm{m} \cdot \sigma_{\mathrm{CO}_{2}} \cdot \mathrm{N}_{\mathrm{M}} \cdot \mathrm{L}\right)\right) \\
& +\frac{\beta_{0}}{\mathrm{~m} \cdot \sigma_{\mathrm{CO}_{2}} \cdot \mathrm{L}} \cdot\left(1-\exp \left(-\mathrm{m} \cdot \sigma_{\mathrm{CO}_{2}} \cdot \mathrm{N}_{\mathrm{M}} \cdot \mathrm{L}\right)\right),
\end{aligned}
$$

where $\chi$ is a constant not depending on $\mathrm{N}_{\mathrm{M}}$.

We approximated our experimental dependence by the function $\mathrm{y}=$ $A \cdot(1-\exp (-B \cdot x))+C \cdot x \cdot(1-\exp (-2 B \cdot x))$. The obtained curve is shown on 
Figure 2; one can see that the function describes the experimental results quite well. It is also seen by the character of the dependence that at sufficiently high pressures the relation $\left|\Delta \mathrm{N}_{\mathrm{M}}\right|_{\mathrm{ms}} / \mathrm{n}_{\mathrm{eff}(\mathrm{UV})}$ should be described by the function $\mathrm{y}=1+\vartheta \cdot \mathrm{N}_{\mathrm{M}}$. Such type of dependence was really observed in our experiments.

At high pressures of $\mathrm{CF}_{2} \mathrm{HCl}$ one can see the slight decrease of the experimental value of $\mathrm{CF}_{2}$ concentration as compared to the calculated curve. This decrease more probably can be caused by the violation of an assumption about constancy of dissociation yield $\beta_{0}$ while $\mathrm{CF}_{2} \mathrm{HCl}$ pressure changes.

The plot of the relation of the probing beam energy absorbed in the cell to the energy of the incident beam vs number of $\mathrm{CO}_{2}$-laser pulse at the initial $\mathrm{CF}_{2} \mathrm{HCl}$ pressure of 20 Torr is presented in Figure 3. One can see that the initial exponential fall in $\left(I_{0}-I\right) / I_{0}(n)$ is replaced after $n \approx 140$ by the plateau, and when $n>200$ the UV beam passes the cell without losses in its intensity. The assumption that all the molecules $\mathrm{CF}_{2} \mathrm{HCl}$ had already been dissociated up to this moment is incorrect: the mass-spectrometer analysis of the irradiated mixture revealed that after the 200th laser pulse $\mathrm{CF}_{2} \mathrm{HCl}$ content in the gas is equal to $37 \%$ of its initial value. The same character has the dependence of the relation of the $\mathrm{CO}_{2}$-laser energy absorbed in the cell to the energy at the entrance of the cell (curve 2): when $n>120$ the absorption of IR emission does not change. Those dependencies may be caused by the

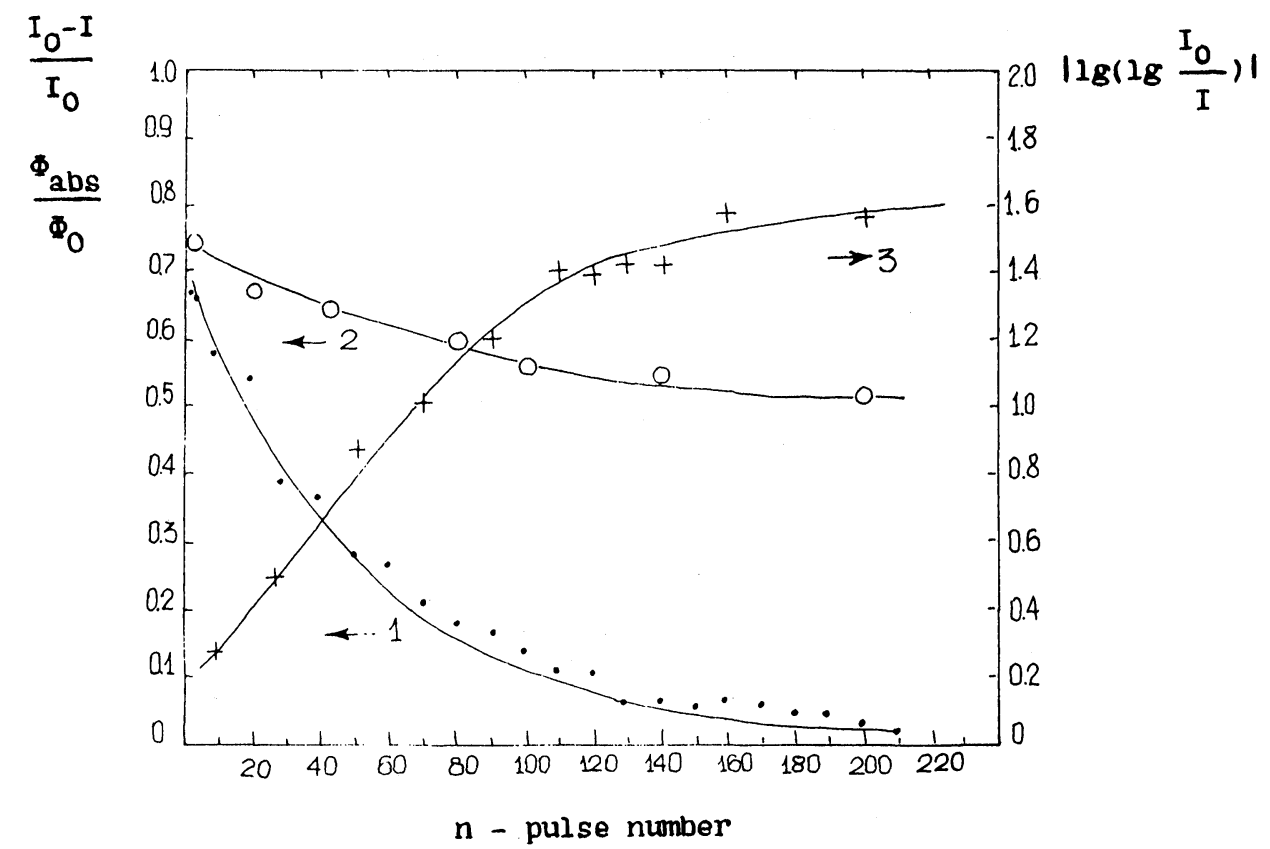

Figure 3 Plot of $\left(I_{0}-I\right) / I_{0}$-fraction of UV-beam energy $(\lambda=248 \mathrm{~nm})$ absorbed in the cell (curve 1) and of relation of $\mathrm{CO}_{2}$-laser energy absorbed in the cell to the energy at the entrance of the cell (curve 2 ) vs $\mathrm{CO}_{2}$-laser pulse number. Initial $\mathrm{CF}_{2} \mathrm{HCl}$ pressure 20 torr. Curve 3, the dependence of $|\lg |\left(\lg \left(I_{0} / I\right)\right) \|$ upon the number of the pulse. $I_{0}$ and $I$, the energy of UV probing beam respectively at the entrance and at the exit of the cell. 
accumulation of some substance in the cell as a number of pulses rises, which gives rise to fast relaxation of the excited molecules $\mathrm{CF}_{2} \mathrm{HCl}$. As the concentration of this substance increases, the moment is reached when both dissociation of $\mathrm{CF}_{2} \mathrm{HCl}$ molecules and reaction of $\mathrm{C}_{2} \mathrm{~F}_{4}$ formation at the collisions of vibrationally excited molecules $\mathrm{CF}_{2} \mathrm{HCl}$ are ceased. As a result, firstly, $\mathrm{CF}_{2}$-radicals could not be detected in the gas after $\mathrm{CO}_{2}$-laser pulse, and, secondly, as $\mathrm{CF}_{2} \mathrm{HCl}$ remains unchanged so does the part of IR irradiation, absorbed by the mixture. Besides this, there is one practical conclusion following the experimental results: in order to obtain reliable data gas should be irradiated by the limited number of $\mathrm{CO}_{2}$-laser pulses. The permissible number of pulses one can find from the condition of conservation of the linearity of the dependence $|\lg |\left(\lg \left(\mathrm{I} / \mathrm{I}_{0}\right)\right) \|_{(\mathrm{n})}$. Figure 3 demonstrates that this linearity has been kept up to the 60th pulse.

Only two substances are accumulated in the cell; $\mathrm{C}_{2} \mathrm{~F}_{4}$ and $\mathrm{HCl}$. To answer the question how does each of them influence the relaxation of the excited molecules $\mathrm{CF}_{2} \mathrm{HCl}$ we carried out the experiments with model mixtures. The model mixtures were prepared on the basis of the ratio of gaseous components generated in the cell after its irradiation by 200 pulses of $\mathrm{CO}_{2}$-laser. The values of $\mathrm{CF}_{2} \mathrm{HCl}, \mathrm{C}_{2} \mathrm{~F}_{4}$ and $\mathrm{HCl}$ pressures after the 200th pulse at various initial values of $\mathrm{CF}_{2} \mathrm{HCl}$ pressure, determined using mass-spectrometer analysis, are presented in Table 1. When $\mathrm{CF}_{2} \mathrm{HCl}$ relaxation on $\mathrm{C}_{2} \mathrm{~F}_{4}$ was investigated the model mixture was prepared from these two gases, their partial pressures being chosen equal to those which were observed in the cell irradiated by $200 \mathrm{CO}_{2}$-laser pulses. Figure 4 shows how does the portion of the absorbed in the cell IR beam energy $\Phi_{\text {abs. }} / \Phi_{0}$ (where $\Phi_{\text {abs. }}=\Phi_{0}-\Phi_{\mathrm{L}}$ ) change when irradiating the real mixture of gases $\mathrm{CF}_{2} \mathrm{HCl}, \mathrm{C}_{2} \mathrm{~F}_{4}$ and $\mathrm{HCl}$, obtained by the exposing of the neat $\mathrm{CF}_{2} \mathrm{HCl}$ to $200 \mathrm{CO}_{2}$-laser pulses, the same dependence for the model mixture (consisting only from $\mathrm{CF}_{2} \mathrm{HCl}$ and $\mathrm{C}_{2} \mathrm{~F}_{4}$ ) also being represented. One can consider that in the first approximation the curves coincide. It means that $\mathrm{C}_{2} \mathrm{~F}_{4}$ is the main relaxant of excited molecules $\mathrm{CF}_{2} \mathrm{HCl}$. A little more higher absorption of IR beam by the real mixture as compared to the model mixture can be explained by the additional presence of $\mathrm{HCl}$. It is interesting that the energy absorption in gas does not lead to $\mathrm{CF}_{2} \mathrm{HCl}$ dissociation: in the whole range of investigated pressures both for real and model mixtures the absorption at $\lambda=248 \mathrm{~nm}$ was not observed. $\mathrm{C}_{2} \mathrm{~F}_{4}$ formation owing to direct interaction of excited molecules $\mathrm{CF}_{2} \mathrm{HCl}$ was not also observed: mass-spectrometer analyses showed that starting with the 200th pulse $\mathrm{CF}_{2} \mathrm{HCl}$ concentration remained unchanged.

The experiments in which the influence of $\mathrm{HCl}$ on $\mathrm{CF}_{2} \mathrm{HCl}$ MPD yield was investigated were carried out for the model mixture $\mathrm{CF}_{2} \mathrm{HCl}: \mathrm{HCl}=$

Table 1 The pressures of the mixture gas-phase components (torr) after $\mathrm{CF}_{2} \mathrm{HCl}$ irradiation with 200 $\mathrm{CO}_{2}$-laser pulses

\begin{tabular}{lllllllllll}
\hline Initial pressure $\mathrm{CF}_{2} \mathrm{HCl}$ & 2 & 4 & 6 & 8 & 10 & 12 & 14 & 16 & 18 & 20 \\
\hline Final Pressure $\mathrm{CF}_{2} \mathrm{HCl}$ & 1.98 & 2.5 & 3.3 & 4.18 & 4.8 & 5.43 & 6.14 & 6.84 & 7.2 & 7.5 \\
$\mathrm{C}_{2} \mathrm{~F}_{4}$ & 0.01 & 0.75 & 1.35 & 1.9 & 2.6 & 3.28 & 3.93 & 4.58 & 5.4 & 6.25 \\
$\mathrm{HCl}$ & 0.02 & 1.5 & 2.7 & 3.8 & 5.2 & 6.56 & 7.86 & 9.16 & 10.8 & 12.5 \\
\hline
\end{tabular}




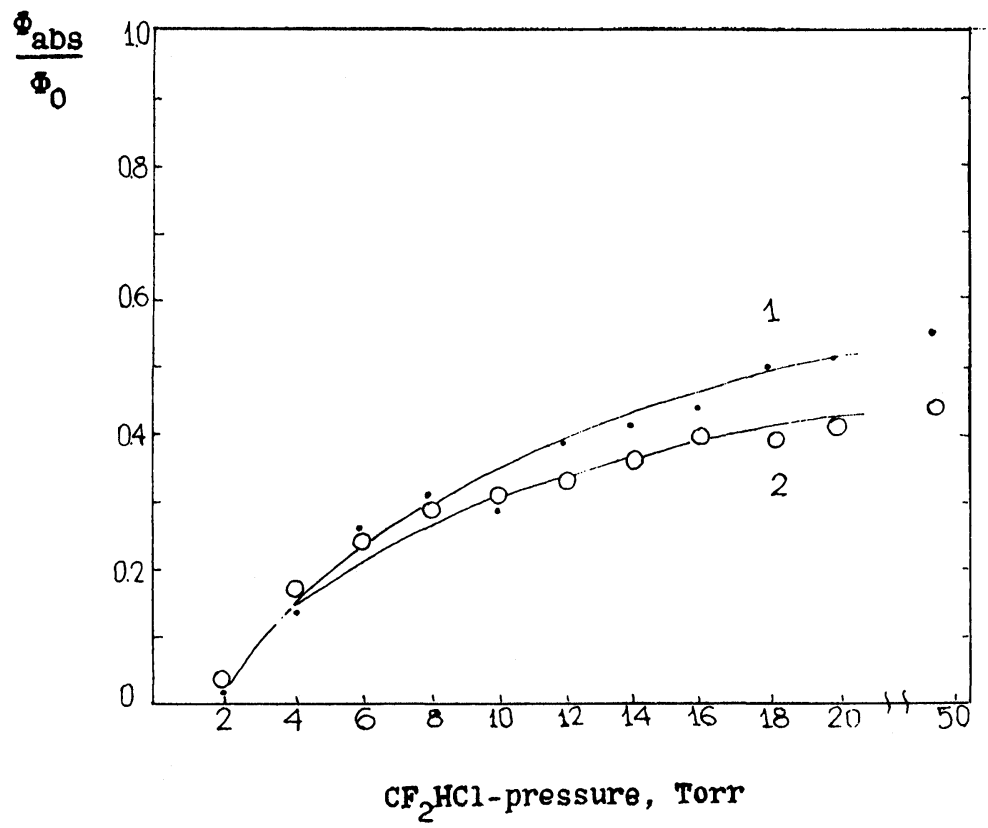

Figure 4 Plot of fraction of $\mathrm{CO}_{2}$-laser energy absorbed in the cell vs initial gas pressure: (1) for the 200th pulse to the cell with neat $\mathrm{CF}_{2} \mathrm{HCl}$. (2) For the first pulse to the cell with model mixture $\mathrm{CF}_{2} \mathrm{HCl}+\mathrm{C}_{2} \mathrm{~F}_{4}$, prepared according to Table 1 .

7.5 Torr:12.5 Torr. The comparison of data of the dependence of UV-beam attenuation on the number of $\mathrm{CO}_{2}$-laser pulses for this mixture and for the neat $\mathrm{CF}_{2} \mathrm{HCl}$ points out their full identity (see Figure 5). This means that in our circumstances $\mathrm{HCl}$ practically does not affect the process of $\mathrm{CF}_{2} \mathrm{HCl}$ multiphoton dissociation. But at the same time the adding of hydrogen chloride to $\mathrm{CF}_{2} \mathrm{HCl}$ increases the amount of IR radiation energy absorbed by the gas (curves 2 and 3 on Figure 5). This increase of the portion of the absorbed energy does not lead, however, to the enhancement of the yield of $\mathrm{C}_{2} \mathrm{~F}_{4}$ formation reaction at $\mathrm{CF}_{2} \mathrm{HCl}$ collisions. Really, the results of the comparison of mass-spectral peaks heights $\mathrm{m} / \mathrm{e}=51$ (molecule $\mathrm{CF}_{2} \mathrm{HCl}$ ) $\mathrm{N}_{200}$ and $\mathrm{N}_{0}$, respectively after the irradiation of the gas with 200 pulses and before the irradiation, for the model mixture $\mathrm{CF}_{2} \mathrm{HCl}+\mathrm{HCl}$ and for the neat $\mathrm{CF}_{2} \mathrm{HCl}$ show that $\left(\mathrm{N}_{200} / \mathrm{N}_{0}\right)_{\mathrm{CF}_{2} \mathrm{HCl}} /\left(\mathrm{N}_{200} / \mathrm{N}_{0}\right)_{\mathrm{CF}_{2} \mathrm{HCl}+\mathrm{HCl}}=0.95 \pm 0.01$, i.e. the dissociation yield in the model mixture is even lower than in the neat $\mathrm{CF}_{2} \mathrm{HCl}$. But it means that the additional IR radiation energy absorbed by the gas due to increase of $\mathrm{HCl}$ content is consumed mainly to gas heating, without essential influence on the processes of dissociation and interaction between vibrationally excited molecules $\mathrm{CF}_{2} \mathrm{HCl}$.

Figure 6 shows how the total $\mathrm{CF}_{2} \mathrm{HCl}$ MPD-yield and $\mathrm{CF}_{2}$-radicals yield after the first $\mathrm{CO}_{2}$-laser pulse change with increasing of $\mathrm{C}_{2} \mathrm{~F}_{4}$ content in mixture. One can see that the yield of $\mathrm{CF}_{2}$-radicals diminishes in two times at $\mathrm{C}_{2} \mathrm{~F}_{4}$ pressure near 1.5 Torr. Those data permitted us to evaluate the rate constand of the reaction 


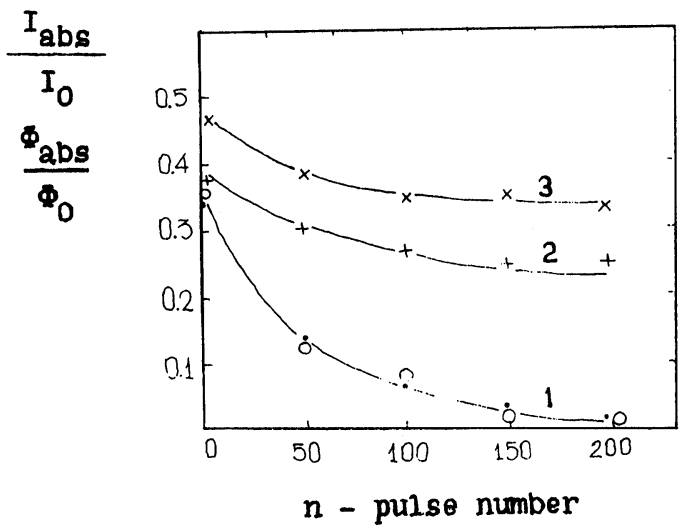

Figure 5 Development with a pulse number of the attenuation degree of UV beam for the mixture $\mathrm{CF}_{2} \mathrm{HCl}: \mathrm{HCl}=7.5$ torr: 12.5 torr $(\cdot)$ and for $\mathrm{CF}_{2} \mathrm{HCl}$ with initial pressure 7.5 torr $(\mathrm{O})$ (curve 1 ). Curve 2, the dependence on the pulse number of the relative absorption of $\mathrm{CO}_{2}$-laser pulse energy for $\mathrm{CF}_{2} \mathrm{HCl}$ at initial pressure 7.5 torr. Curve 3, the same for the mixture $\mathrm{CF}_{2} \mathrm{HCl}: \mathrm{HCl}=7.5$ torr: 12.5 torr.

of $\mathrm{CF}_{2} \mathrm{HCl}$ deactivation on $\mathrm{C}_{2} \mathrm{~F}_{4}$. Really in order to weaken the process of dissociation in two times the probability of the molecule's transition to the lower level, from which the dissociation is no longer possible, should become equal to the probability of $\mathrm{CO}_{2}$-laser quantum absorption by $\mathrm{CF}_{2} \mathrm{HCl}$ molecule. Or, in other words, relaxation time should become equal to excitation time: $\tau_{\text {rel }}=\tau_{\text {exc }}$. The relaxation time $\tau_{\text {rel }}=1 /\left(\mathrm{k}_{\mathrm{rel}} \cdot\left[\mathrm{C}_{2} \mathrm{~F}_{4}\right]\right)$. Since during $\mathrm{CO}_{2}$-laser pulse the molecule absorbs 18 $\mathrm{CO}_{2}$-laser quanta one can consider the characteristic time of the excitation of $\mathrm{CF}_{2} \mathrm{HCl}$ molecules, occupying the energy levels situated not far from the dissociation threshold,

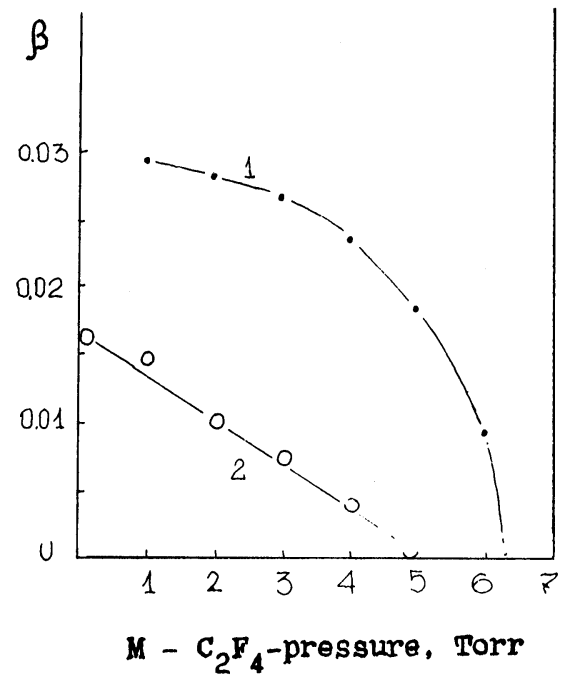

Figure 6 Plot of total $\mathrm{CF}_{2} \mathrm{HCl}$ dissociation yield in one pulse (1) and of $\mathrm{CF}_{2}$-radicals yield (2) in the first pulse for the mixture $\mathrm{CF}_{2} \mathrm{HCl}: \mathrm{C}_{2} \mathrm{~F}_{4}=7.5$ torr: $\mathrm{M}$ vs initial $\mathrm{C}_{2} \mathrm{~F}_{4}$ pressure. 
to be equal to $\left(10^{-6} / 18\right) \mathrm{s}$. While comparing those values one can get an estimation of the rate constant of $\mathrm{CF}_{2} \mathrm{HCl}$ relaxation on $\mathrm{C}_{2} \mathrm{~F}_{4}: \mathrm{k}_{\mathrm{rel}} \sim 5 \cdot 10^{-10} \mathrm{~cm}^{3} \mathrm{~s}^{-1}$. Thus, the relaxation of vibrationally excited $\mathrm{CF}_{2} \mathrm{HCl}$ molecule occurs almost at every collision with $\mathrm{C}_{2} \mathrm{~F}_{4}$ molecule. This estimate is made under the supposition that $\mathrm{CF}_{2} \mathrm{HCl}$ molecule is excited over the dissociation threshold only by 1-2 quanta of $\mathrm{CO}_{2}$-laser, where the time of the dissociation is less than $10^{-7} \mathrm{~s}^{17}$

In our experiments the dissociation yield does not exceed a few percent, that is why one can consider that at $\mathrm{C}_{2} \mathrm{~F}_{4}$ pressures higher than 4 Torr each excited $\mathrm{CF}_{2} \mathrm{HCl}$ molecule is surrounded by approximately a hundred of "cold" $\mathrm{C}_{2} \mathrm{~F}_{4}$ molecules. The first stage of $\mathrm{CF}_{2} \mathrm{HCl}$ vibrational energy relaxation is the resonance transfer of energy to $\mathrm{C}_{2} \mathrm{~F}_{4}$ molecules promoted by the nearness of the frequencies of the bands $v_{8}$ $\left(1127 \mathrm{~cm}^{-1}\right), v_{4}+v_{6}\left(1214 \mathrm{~cm}^{-1}\right)$ and others of $\mathrm{CF}_{2} \mathrm{HCl}$ and of the bands $v_{12}$ $\left(1186 \mathrm{~cm}^{-1}\right) \mathrm{C}_{2} \mathrm{~F}_{4}$; and also of the bands $v_{2}\left(1313 \mathrm{~cm}^{-1}\right)$ and $v_{7}\left(1351 \mathrm{~cm}^{-1}\right)$ $\mathrm{CF}_{2} \mathrm{HCl}$ and the band $v_{10}\left(1337 \mathrm{~cm}^{-1}\right) \mathrm{C}_{2} \mathrm{~F}_{4} \cdot{ }^{19,20}$ Then the vibrationally excited molecules loose their energy due to $\mathrm{V}-\mathrm{T}$ relaxation. The same relaxation processes, where the presence of the frequency resonances between the excited and quenching molecules plays an important role, were observed for $\mathrm{SF}_{6}$ multiphoton dissociation in the presence of $\mathrm{NH}_{3}$ and $\mathrm{C}_{2} \mathrm{H}_{4},{ }^{17}$ or for $\mathrm{CF}_{2} \mathrm{HCl} \mathrm{MPD}$ in the presence of $\mathrm{CF}_{3} \mathrm{Cl}^{21}$

Within the frames of the described mechanism one can also explain a weak action of $\mathrm{HCl}$ on relaxation of excited molecules $\mathrm{CF}_{2} \mathrm{HCl}$ : the energy of the bands $v_{1}$ $\left(3023 \mathrm{~cm}^{-1}\right)$ and $v_{1}+v_{6}\left(3435 \mathrm{~cm}^{-1}\right)$ appears to be the most close to the energy of the level $\mathrm{v}=1 \mathrm{HCl}\left(\sim 2900 \mathrm{~cm}^{-1}\right)$; but because of the significant energy defect vibrational-vibrational exchange in the system $\mathrm{CF}_{2} \mathrm{HCl}+\mathrm{HCl}$ would not be fast.

\section{CONCLUSION}

For the first time the txistence of $\mathrm{C}_{2} \mathrm{~F}_{4}$ formation at the binary collisions of vibrationally excited molecules $\mathrm{CF}_{2} \mathrm{HCl}$ was directly confirmed. The input of this reaction to the products formation at $\mathrm{CF}_{2} \mathrm{HCl}$ pressures of tens Torr was shown to become predominant. Discovering the fast relaxation of vibrationally excited $\mathrm{CF}_{2} \mathrm{HCl}$ molecules on the product's molecules $\mathrm{C}_{2} \mathrm{~F}_{4}$ due to the resonance energy exchange between those molecules seems to be the second significant result of this work; the rate constant of this process was estimated to be $5 \cdot 10^{-10} \mathrm{~cm}^{3} \mathrm{~s}^{-1}$. The presence of the process of "self-relaxation" restricts the degree of the initial matter conversion to the products at the irradiation of gas in the limited volume.

\section{References}

1. V. S. Letokhov, Uspechi Fiz. Nauk (Sov.), 148, 123 (1986).

2. M. Gauthier, P. A. Hackett, C. Willis, In : Synthesis and Applications of Isotopically Labeled Compounds (Elsevier, Amsterdam, 1983), pp. 413-414.

3. A. V. Evseev, V. B. Laptev, A. A. Puretzkyi, E. A. Ryabov, N. P. Furzikov, In: Abstracts of the XIIth All-Union Conference on Coherent and Nonlinear Optics (Moscow, 1985), vol. II, p. 667.

4. M. Gauthier, C. G. Cureton, P. A. Hackett, C. Willis, Appl. Phys., B28, 43 (1982).

5. A. M. Velichko, A. A. Nadeikin, A. I. Nikitin, High Energy Chem. (Sov.), 23, 456 (1989).

6. W. Fuß, J. Göthel, K. L. Kompa, M. Ivanenko, W. E. Schmid, In : Abstracts of the XIVth International Conference on Coherent and Nonlinear Optics (Leningrad, 1991), vol. I, p. 59. 
7. V. B. Laptev, A. A. Puretzkyi, E. A. Ryabov, N. P. Furzikov, Sov. J. Quantum Electron., 15, 606 (1988).

8. O. N. Avatkov, V. M. Vetsko, D. I. Dzneladze, G. G. Esadze, A. V. Kaminskii, A. G. Kudziev, T. A. Kudziev, High Energy Chem. (Sov.), 22, 167 (1988).

9. A. M. Velichko, A. A. Nadeikin, A. I. Nikitin, High Energy Chem. (Sov.), 23, 529 (1989).

10. R. K. Laird, E. B. Andrews, R. F. Barrow, Trans. Faraday Soc., 46, 803 (1950).

11. W. J. R. Tyerman, Trans. Faraday Soc., 65, 1188 (1969).

12. A. P. Modica, J. Phys. Chem., 72, 4594 (1968).

13. S. K. Sarkas, D. K. Palit, K. V. S. Rama Rao, J. P. Mittal, Chem. Phys. Lett., 131, 303 (1986).

14. H. Okabe, Photochemistry of Small Molecules (John Wiley and Sons, Inc., 1978).

15. N. D. Aksenenko, M. L. Baranochnikov, O. V. Smolin, In: Microelectronic Photodetectors (Energoatomizdat, Moscow, 1984).

16. F. W. Dalby, J. Chem. Phys., 41, 2297 (1964).

17. V. N. Bagratashvili, V. S. Letokhov, A. A. Makarov, E. A. Ryabov, Multiphoton Processes in Molecules in the Infrared Laser Field (Itogi Nauki i Techniki, vol. 2, VINITI, Moscow, 1981).

18. J. C. Stephenson, D. S. King, J. Chem. Phys., 69, 1485 (1978).

19. A. Brown, D. C. McKean, J. L. Duncan, Spectrochimica Acta, 44A, 553 (1988).

20. J. R. Nielsen, H. H. Claassen, D. C. Smith, J. Chem. Phys., 18, 812 (1950).

21. A. Outhouse, P. Lawrence, M. Gauthier, P. A. Hackett, Appl. Phys., B36, 63 (1985). 